\title{
Kinetic assessment of the anaerobic treatment of piggery wastewaters using an EGSB reactor with Cuban natural zeolite
}

\author{
Tania Pérez-Pérez ${ }^{1}$, Arletty Funcada-Martínez ${ }^{2}$, Ania Cabrera-Díaz ${ }^{2}$, Luis E. Guerra-Díaz ${ }^{2}$, \\ Deny Oliva-Merencio $^{3}$, Zhenia Milán ${ }^{4}$, Ileana Pereda-Reyes ${ }^{2+}$ \\ ${ }^{1}$ Institute of Animal Science, San José de las Lajas, Mayabeque, Cuba \\ ${ }^{2}$ Study Center for Process Engineering (CIPRO), Universidad Tecnológica de La Habana "José A. Echeverría" (Cujae), Marianao, La Habana, Cuba \\ ${ }^{3}$ Study Center for Renewable Energy Technologies (CETER), Universidad Tecnológica de La Habana "José A. Echeverría" (Cujae), Marianao, La \\ Habana, Cuba \\ ${ }^{4}$ Central District Wastewater Treatment Plant, Miami Dade County, Florida, USA
}

\begin{abstract}
Large pig farms generate enormous volumes of wastewater without proper treatment before discharge. High-rate anaerobic reactors as the expanded granular sludge bed (EGSB) are rarely reported for that purpose. In this study, an EGSB reactor with Cuban natural zeolite addition was evaluated for treating piggery wastewaters at lab scale. This study was conducted at different organic loading rate (OLR) ranging from 0.32 to 6.13 gcoD/Ld with a constant hydraulic retention time (HRT) of $12 \mathrm{~h}$. The evolution of several control and operational parameters as the soluble chemical oxygen demand (COD) demonstrated a proper bioreactor performance to treat piggery wastewater. The results showed that the addition of natural zeolite at $40 \mathrm{~g}_{z e} / \mathrm{L}_{\text {reactor }}$ in EGSB reactor results in COD efficiencies over 70\%, despite of the fluctuations of fed wastewater characteristics. The kinetic study demonstrates that, the modified Stover-Kincannon model was found to be appropriate for EGSB reactor. The effluent soluble COD was predicted with high determination coefficient. The maximum removal rate constant $\left(\mathrm{U}_{\max }\right)$ and saturation value constant $\left(\mathrm{K}_{\mathrm{B}}\right)$ were reported for a first time for the EGSB reactor with values of 10.2 and $11.8 \mathrm{~g} \mathrm{CoD} / \mathrm{Ld}$, respectively. Methane yield for both, batch and continues experiments, were in the range from 214.5 to $299.8 \mathrm{~mL}_{\mathrm{CH} 4} / \mathrm{g}_{\mathrm{COD}}$
\end{abstract}

Keywords: Anaerobic digestion, Expanded granular sludge bed reactor (EGSB), Natural zeolite, Piggery wastewaters, Stover-Kincannon model

\section{Introduction}

Animal manure is currently one of the main wastes in various countries due to intensive animal handling. This fact has become a huge challenge that must be correctly dealt without increasing the environmental impact. Specifically, the swine manure is a complex substrate that contains high concentrations of nitrogenous compounds, phosphorus, suspended solids and heavy metals [1]. In addition, high content of biodegradable organic matter and balanced amounts of macro and micronutrients are present which are favorable for the growth of anaerobic microorganisms. Inadequate disposal of these wastes causes high pollution including groundwater, pathogen contamination and greenhouse gas emissions. In Cuba, the animal manure is usually treated in lagoon systems, which generates high concentrations of $\mathrm{CH}_{4}, \mathrm{NH}_{3}, \mathrm{CO}_{2}$ and $\mathrm{H}_{2} \mathrm{~S}$ [2].

Anaerobic granular sludge processes, i.e., the up-flow anaerobic sludge bed (UASB) and EGSB reactors, are a promising technology for treating organic pollutants due to their effectiveness in energy production, limited nutrient requirements and low sludge production. The formation of granular sludge is a necessary condition for the achievement of a satisfactory operation, where the efficiency of the reactor depends mainly on the concentration of active biomass and the organic loads fed to the reactor [3].

The EGSB reactors are attractive due to several advantages, among which stand out, a simple design, high efficiency in treatment, low operating costs and its potential to generate renewable energy [4]. The major inconvenience of the UASB and EGSB reactors is the long starting-up periods because of granulation process which often depends heavily on the biomass growth. Some studies [5,

Received June 23, 2021 Accepted September 06, 2021

${ }^{\dagger}$ Corresponding author

E-mail: ileana@quimica.cujae.edu.cu

Tel: +5372663403

ORCID: 0000-0001-6517-4202 
6] suggest that this inconvenience can be enhanced or improved with addition of support material during start-up of reactor. However, this inevitably increases the cost of the process and makes the operation more complex. Despite this, with the use of support materials in anaerobic digestion processes, the granulation time of the sludge is shortened [7].

On the other hand, natural zeolites have been valued by its attractive physical and chemical properties that are of great interest for the scientific community. Its structure and physical properties are ideal for the biological processes of sewage treatment [8]. In addition, it is capable of retaining high concentrations of microbial flora in the biofilm, making it possible to achieve the higher COD conversion rates, even at the high OLR and low HRT. The effectiveness of EGSB reactor using zeolite as a support material has been reported by Pérez-Pérez [9, 10] treating a synthetic wastewater.

Additionally, kinetic assessment under continuous regimen is a valuable tool to describe and simulate the performance of bioreactors in order to provide a more accurately scale-up of the process. The modified Stover-Kincannon model is one of the most widely used to determine kinetic parameters not only in immobilized [11] but also in "fluidized" granules systems [12]. This modified model provides flexibility to evaluate the degradation rate of the substrate independent of the kinetic reaction, at different organic loads.

In this regard, the objective of the present study is to evaluate the effectiveness of an EGSB reactor using Cuban natural zeolite as a support material for treating piggery wastewater. To accomplish this objective, the process was assessed by the modified StoverKincannon model setting off kinetic data that, to best of our knowledge, have not been previously reported.

\section{Material and Methods}

\subsection{Piggery Wastewater and Natural Zeolite Characteristics}

Piggery wastewaters (S) were provided from a pig breeding farm of the Institute of Animal Science (ICA, acronym in Spanish), Cuba. The main characteristics of piggery wastewaters used for Laboratory experiments are shown at Table 1. It was collected twice a week and refrigerated at $6 \pm 2{ }^{\circ} \mathrm{C}$.

The anaerobic sludge used as inoculum (I) was collected from a fixed-dome anaerobic digester treating cattle manure and operated for more than 4 years in the Farm "Marta", Artemisa, Cuba. The inoculum had an average $\mathrm{pH}$ of 7.15 and $12.38 \mathrm{~g} / \mathrm{L}$ of total solids (TS) and $8.36 \mathrm{~g} / \mathrm{L}$ of total volatile solids (TVS).

Natural zeolite was added according to previous studies by Pérez-Pérez et al. [9] at a concentration of $40 \mathrm{~g}$ of zeolite/L of reactor. Natural zeolite was provided by the "El Chorrillo" ore located at Camagüey, Cuba, with the following composition:
Clinoptilolite-heulandite (22.50\%), Mordenite (36.05\%), Montmorillonite (22.50\%), and Calcite (4.50\%). The main elements that compose it are: $\mathrm{SiO}_{2}$ (58.94\%), $\mathrm{Al}_{2} \mathrm{O}_{3}$ (11.91\%), $\mathrm{CaO}$ (6.71\%), $\mathrm{Fe}_{2} \mathrm{O}_{3}$ (2.30\%), $\mathrm{MgO}(0.76 \%), \mathrm{Na}_{2} \mathrm{O}$ (1.56\%), $\mathrm{K}_{2} \mathrm{O}$ (1.14\%) and $13.2 \%$ residue on ignition. Zeolite was mechanically sieved to a particle size between 0.15 and $0.20 \mathrm{~mm}$.

\subsection{Anaerobic Processes}

The lab experiment was performed in a $0.63 \mathrm{~L}$ tubular acrylic EGSB reactor with a tube and separator with diameters of 3.3 and $6.5 \mathrm{~cm}$, respectively as shown in Fig. 1. The heights of the tube and separator, respectively, were 50 and $10 \mathrm{~cm}$. About 30\% (V $=200 \mathrm{~mL}$ ) of the effective reactor volume was inoculated with the anaerobic sludge.

The adaptation period was conducted at organic loading rate (OLR) of $0.5 \mathrm{gCOD} / \mathrm{Ld}$ for $9 \mathrm{~d}$. Theoretical hydraulic retention time (HRT) was $12 \mathrm{~h}$, with an influent flow rate (Qin) of $0.9 \mathrm{~mL} / \mathrm{min}$ and a recirculation ratio $(\mathrm{Rr})$ of 44.4. The wastewater was fed using a peristaltic pump at an up-flow mode reactor. In order to keep an up-flow velocity of $6 \mathrm{~m} / \mathrm{h}$, another peristaltic pump was used for recirculation of effluent. The reactor was operated in continuous mode for $70 \mathrm{~d}$.

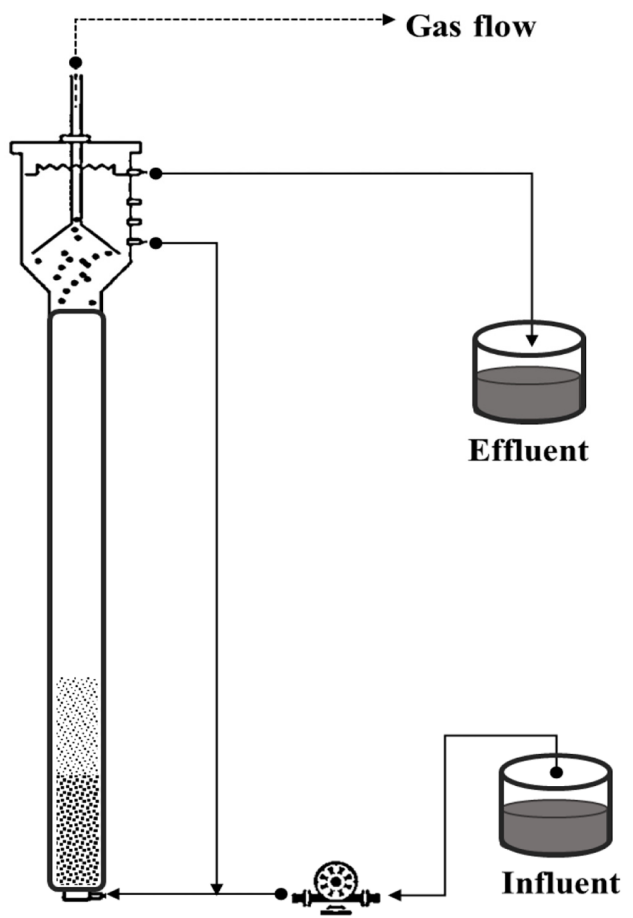

Fig. 1. Schematic of the experimental unit.

Table 1. Main Characteristics of the Piggery Wastewater $(n=12)$

\begin{tabular}{lcccccccc}
\hline Parameter & $\mathbf{p H}$ & $\begin{array}{c}\text { EC } \\
(\boldsymbol{\mu S} / \mathbf{c m})\end{array}$ & $\begin{array}{c}\text { VFA/TIC } \\
(\mathbf{m g} / \mathbf{L})\end{array}$ & $\begin{array}{c}\text { Soluble COD } \\
(\mathbf{m g} / \mathbf{L})\end{array}$ & $\begin{array}{c}\text { TS } \\
(\mathbf{m g} / \mathbf{L})\end{array}$ & $\begin{array}{c}\text { VS } \\
(\mathbf{m g} / \mathbf{L})\end{array}$ & $\begin{array}{c}\text { TKN } \\
(\mathbf{m g} / \mathbf{L})\end{array}$ & $\begin{array}{c}\text { N-NH } \\
(\mathbf{m g} / \mathbf{L})\end{array}$ \\
\hline \multirow{2}{*}{ Average $\left(^{*}\right)$} & 7.71 & $1,446.0$ & 764 & $1,386.0$ & $3,673.0$ & $2,503.0$ & 222.8 & 60.2 \\
& $(0.67)$ & $(165.9)$ & $(248)$ & $(1,266.9)$ & $(795.4)$ & $(610.1)$ & $(178.0)$ & $(24.2)$ \\
\hline
\end{tabular}

$\left({ }^{*}\right)$ In parentheses are standard deviations (SD) 
In order to countercheck methane production as a control parameter in EGSB reactor, batches based on the fermentation of organic materials guidelines were carried out [13]. Two COD/VSS ratios were applied to batch reactors: 0.5 and 0.75 . Nine $0.5 \mathrm{~L}$ capacity reactors were set with an effective volume of $0.4 \mathrm{~L}$ to add the mixture of substrate and inoculum. Reactors were manually agitated at least once a day to avoid content stratification. The batch tests were conducted in triplicates at $37 \pm 1^{\circ} \mathrm{C}$ for a time period of $20 \mathrm{~d}$, until methane production declined in all reactors. To ensure operating temperature, batch reactors were placed in thermostat water-baths. Methane production was measured twice a day by a liquid displacement using a $15 \%(\mathrm{w} / \mathrm{v}) \mathrm{NaOH}$ solution. Methane volume was reported at $273 \mathrm{~K}$ and $101.3 \mathrm{kPa}$ and corrected with a blank reactor with inoculum for kinetic assessment.

\subsection{Analytical Methods}

Total solids and total volatiles solids (2540D) were determined following the Standard Methods for Examination of Water and Wastewater [14]. The soluble chemical oxygen demand (COD; $5220 \mathrm{D})$ by the open reflux method (dichromate method) was performed on filtered samples $(0.45 \mu \mathrm{m})$. The $\mathrm{pH}$ was determined by a CRISSON PH 25 pH-meter. The total and ammoniacal nitrogen concentrations were measured according to the Kjeldahl method with a GERHARDT Vapodet, by digestion followed by distillation and titration. The VFA/TIC ratio was carried out with the two-point titration technique (to a $\mathrm{pH}$ of 5.0 and 4.4, respectively), described by Lossie and Pütz [15] on filtered samples $(0.45 \mu \mathrm{m})$. The average value of three replicates was used in all analyzed samples.

\subsection{Estimation of Kinetic Parameters}

First order exponential model was applied to batch experiments in order to determine the methane yield according to Pagés-Díaz et al. [16]. The adjustment to the model was carried out by a non-linear regression analysis, using the Statgraphics Centurion XVII.

The biodegradation kinetics for EGSB reactor operation was assessed using the modified Stover-Kincannon model applied to experimental data. The saturation value constant $\left(K_{\mathrm{B}}\right)$ and the rate of maximum substrate utilization constant $\left(\mathrm{U}_{\max }\right)$, both in $\mathrm{g}_{\mathrm{CoD}} / \mathrm{Ld}$, were obtained from the linear graph of the inverse of the organic loading removal rate (OLRr) versus the inverse of the total organic loading rate (OLR) as clearly reported by Jijai et al. [17] and Abyar et al. [12].

In this study, the modified Stover-Kincannon model was applied for the kinetic evaluation of COD and TKN profile during the time course of the experiment. The COD and TKN effluent concentration were predicted, then the removal efficiency of COD and TKN were determined. One-way ANOVA and Tukey's multi-comparison test were conducted to assess the effects of Cuban natural zeolite addition on the process enhancement in terms of NTK and COD removal efficiency.

\section{Results and Discussion}

\subsection{Characteristics of Piggery Wastewater}

As it can be seen, the average values of piggery wastewater analyzed parameters, along with the standard deviation values express the variability of such parameters. The high fluctuations can be attributed to the cleaning practices of using variable amounts of water to ensure animal welfare while animals are under high temperatures [18]. Different COD values are reported in literature, Boursier et al. [19] conducted a study on four pig farms in France and obtained values in the range of 26,400 and 50,600 mg/L. However, as referred by Sosa et al. [2], in Cuban pig breeding farms, values of COD have been reported in the range of 2,310 to $2,640 \mathrm{mg} / \mathrm{L}$, very similar to the present characterization. Additionally, the volatile solids described wide variability with a range from 1,114 to $5,626 \mathrm{mg} / \mathrm{L}$. Studies conducted by the above-mentioned authors also show variability of this parameter values, from 7,800 to $21,700 \mathrm{mg} / \mathrm{L}$. In this study, the VS/TS ratio had values greater than 0.5 , most of them around 0.68 , which indicates a high biodegradability index.

\subsection{Kinetics Assessment of Discontinuous Regimen}

As previously stated, the batch experiments were developed in order to countercheck the methane yield of the EGSB reactor operation. This parameter is an indicator of the system capability to biodegrade the organic content in substrates. The results working at organic loads 0.5 and 0.75 in terms of $\mathrm{COD}_{\mathrm{S}} / \mathrm{VSS}_{\mathrm{I}}$ ratio $(\mathrm{g} / \mathrm{g})$ and retention time of $20 \mathrm{~d}$ are summarized with the following correlations (Eq. (1) and (2)):

$$
\begin{gathered}
Y_{C H 4}(0.5)=263.5\left(1-e^{-0.2723 t}\right) \\
Y_{C H 4}(0.75)=267.8\left(1-e^{-0.2432 t}\right)
\end{gathered}
$$

From both mathematical expressions it can be calculated that the anaerobic degradation of actual piggery wastewaters yields approximately $266.5 \pm 2.6 \mathrm{~mL}_{\mathrm{CH} 4} / \mathrm{g}_{\mathrm{COD}}$. This piggery wastewater is characterized by soluble and easily degradable compounds that make it a huge potential for biogas production and a proper option to close cycles in a piggery breeding farm [2].

\subsection{EGSB Reactor Performance}

For continuous regimen assessment, soluble COD, VFA/TIC ratio, $\mathrm{pH}$ and temperature were monitored to evaluate the performance of the EGSB reactor during the running process. In this study, wastewater was fed as generated in the pig farm. For that reason, the COD values were low, and to keep the HRT, the applied OLR were lower than the permissible ones for high-rate reactor as EGSB. During the operation, the $\mathrm{pH}$ of effluent ranged between 6.9 and 8.6, indicating a proper conversion of volatile acids to methane. The overall results are described in Table 2.

The volatile fatty acids/ total inorganic carbonate (VFA/TIC) ratio is a parameter recommended by specialized literature for the control of anaerobic digestion processes [20, 21]. For all different applied OLRs, the average VFA/TIC ratio in the effluent remained in a range from 0.01 to 0.20 , which can be considered as a stable condition for EGSB reactor by treating piggery wastewater. Ahring et al. [22] propose that this ratio should fluctuate between 0.10 and 0.35 , although Lossie and Pütz [15] remarked that it can go up to 0.50 without this indicating destabilization of the reactor. Studies conducted by the above-mentioned authors also show that values less than 0.10 indicate adequate degradation. Summarizing, it is a favorable indicator 
Table 2. Summary of the Results through the Operation of the EGSB Reactor with the Addition of Zeolite, Treating Piggery Wastewater $(\mathrm{n}=3$ )

\begin{tabular}{|c|c|c|c|c|c|c|c|c|c|c|c|c|c|c|c|c|}
\hline \multicolumn{17}{|c|}{ OLR (gCOD/Ld) } \\
\hline \multirow{2}{*}{ Parameter } & \multicolumn{2}{|c|}{0.32} & \multicolumn{2}{|c|}{0.65} & \multicolumn{2}{|c|}{0.81} & \multicolumn{2}{|c|}{0.97} & \multicolumn{2}{|c|}{1.77} & \multicolumn{2}{|c|}{2.10} & \multicolumn{2}{|c|}{4.35} & \multicolumn{2}{|c|}{6.13} \\
\hline & $\mathbf{I}$ & $\mathbf{E}$ & I & $\mathbf{E}$ & I & $\mathbf{E}$ & $\mathbf{I}$ & $\mathbf{E}$ & I & $\mathbf{E}$ & I & $\mathbf{E}$ & I & $\mathbf{E}$ & I & $\mathbf{E}$ \\
\hline $\begin{array}{l}\text { COD } \\
(\mathrm{g} / \mathrm{L})\end{array}$ & $\begin{array}{c}0.157 \\
(0.005)\end{array}$ & $\begin{array}{c}0.022 \\
(0.001)\end{array}$ & $\begin{array}{c}0.314 \\
(0.012)\end{array}$ & $\begin{array}{c}0.078 \\
(0.001)\end{array}$ & $\begin{array}{c}0.392 \\
(0.010)\end{array}$ & $\begin{array}{c}0.059 \\
(0.002)\end{array}$ & $\begin{array}{c}0.47 \\
(0.004)\end{array}$ & $\begin{array}{c}0.124 \\
(0.004)\end{array}$ & $\begin{array}{c}0.862 \\
(0.006)\end{array}$ & $\begin{array}{c}0.156 \\
(0.003)\end{array}$ & $\begin{array}{c}1.019 \\
(0.027)\end{array}$ & $\begin{array}{c}0.316 \\
(0.006)\end{array}$ & $\begin{array}{c}2.117 \\
(0.024)\end{array}$ & $\begin{array}{c}0.549 \\
(0.004)\end{array}$ & $\begin{array}{c}2.979 \\
(0.023)\end{array}$ & $\begin{array}{c}0.862 \\
(0.004)\end{array}$ \\
\hline $\begin{array}{l}\text { TKN } \\
\text { (g/L) }\end{array}$ & $\begin{array}{c}0.128 \\
(0.002)\end{array}$ & $\begin{array}{c}0.044 \\
(0.002)\end{array}$ & $\begin{array}{c}0.105 \\
(0.001)\end{array}$ & $\begin{array}{c}0.038 \\
(0.002)\end{array}$ & $\begin{array}{c}0.105 \\
(0.001)\end{array}$ & $\begin{array}{c}0.042 \\
(0.002)\end{array}$ & $\begin{array}{c}0.091 \\
(0.001)\end{array}$ & $\begin{array}{c}0.042 \\
(0.002)\end{array}$ & $\begin{array}{c}0.112 \\
(0.001)\end{array}$ & $\begin{array}{l}0.0042 \\
(0.002)\end{array}$ & $\begin{array}{c}0.136 \\
(0.002)\end{array}$ & $\begin{array}{c}0.028 \\
(0.001)\end{array}$ & $\begin{array}{c}0.56 \\
(0.004)\end{array}$ & $\begin{array}{c}0.28 \\
(0.002)\end{array}$ & $\begin{array}{c}0.756 \\
(0.005)\end{array}$ & $\begin{array}{c}0.42 \\
(0.003)\end{array}$ \\
\hline $\begin{array}{l}\text { VFA/TIC } \\
(\mathrm{g} / \mathrm{L})\end{array}$ & $\begin{array}{c}0.015 \\
(0.000)\end{array}$ & $\begin{array}{c}0.013 \\
(0.000)\end{array}$ & $\begin{array}{c}0.015 \\
(0.000)\end{array}$ & $\begin{array}{c}0.013 \\
(0.000)\end{array}$ & $\begin{array}{c}0.146 \\
(0.001)\end{array}$ & $\begin{array}{c}0.012 \\
(0.000)\end{array}$ & $\begin{array}{c}0.278 \\
(0.002)\end{array}$ & $\begin{array}{c}0.013 \\
(0.000)\end{array}$ & $\begin{array}{c}0.514 \\
(0.002)\end{array}$ & $\begin{array}{c}0.15 \\
(0.000)\end{array}$ & $\begin{array}{c}0.348 \\
(0.002)\end{array}$ & $\begin{array}{c}0.008 \\
(0.000)\end{array}$ & $\begin{array}{c}0.45 \\
(0.003)\end{array}$ & $\begin{array}{c}0.15 \\
(0.001)\end{array}$ & $\begin{array}{c}0.888 \\
(0.003)\end{array}$ & $\begin{array}{c}0.286 \\
(0.001)\end{array}$ \\
\hline $\mathrm{VS} / \mathrm{TS}$ & $\begin{array}{c}0.587 \\
(0.002)\end{array}$ & $\begin{array}{c}0.487 \\
(0.001)\end{array}$ & $\begin{array}{c}0.609 \\
(0.002)\end{array}$ & $\begin{array}{c}0.513 \\
(0.001)\end{array}$ & $\begin{array}{c}0.713 \\
(0.002)\end{array}$ & $\begin{array}{c}0.449 \\
(0.002)\end{array}$ & $\begin{array}{c}0.624 \\
(0.002)\end{array}$ & $\begin{array}{c}0.506 \\
(0.002)\end{array}$ & $\begin{array}{c}0.588 \\
(0.002)\end{array}$ & $\begin{array}{c}0.519 \\
(0.001)\end{array}$ & $\begin{array}{c}0.666 \\
(0.002)\end{array}$ & $\begin{array}{c}0.654 \\
(0.001)\end{array}$ & $\begin{array}{c}0.686 \\
(0.002)\end{array}$ & $\begin{array}{c}0.614 \\
(0.001)\end{array}$ & $\begin{array}{c}0.952 \\
(0.002)\end{array}$ & $\begin{array}{c}0.62 \\
(0.002)\end{array}$ \\
\hline
\end{tabular}

$\left({ }^{*}\right)$ In parentheses are standard deviations (SD)

I - Influent

E - Effluent

to control the process in UASB and EGSB reactors [23]. Therefore, further studies will be directed to accomplish higher OLR by decreasing the HRT.

In the case of soluble COD removal efficiency (nCOD) a greater variability was observed. Efficiencies ranged from 69.2 to $89.2 \%$ (Fig. 2), probably due to substantial changes in influent characteristics (Table 1). However, with the increasing concentration of influent soluble COD up to $3 \mathrm{~g} / \mathrm{L}$, as well as corresponding OLRs, no considerable variability of nCOD and $\mathrm{YCH}_{4}$ was noticed.

The present EGSB results are similar to those previously reported by Pérez-Pérez et al. [10], the lab scale system was evaluated treating synthetic wastewater with $40 \mathrm{~g} / \mathrm{L}$ natural zeolite concentration. The nCOD varied from 77.0-81.0\% under stable conditions but with OLRs higher than the applied in the present study. Song et al. [24] treated swine wastewater in a UASB reactor and obtained about $74 \%$ of nCOD with HRT higher than those used in this study (HRT of $7 \mathrm{~d}$, which was gradually reduced to a final HRT of $3.5 \mathrm{~d}$ ), applying lower OLRs (1.3 \pm 0.5 to $5.8 \pm 0.3 \mathrm{gCOD} / \mathrm{Ld})$. In addition, Duda et al. [18] using a horizontal anaerobic reactor with sludge blanket (HARSB) treated piggery wastewater obtaining nCOD around $47 \%$. The HRTs for the HARSB were similar to

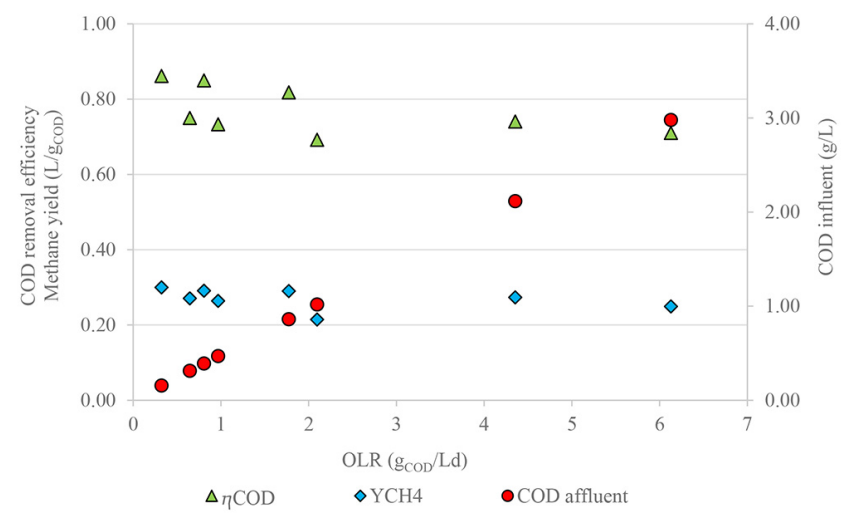

Fig. 2. Performance of the EGSB reactor treating swine wastewater in terms of COD removal efficiency. this study, although OLRs were higher, with values around 11, 12, 18 and $33 \mathrm{gCOD} / \mathrm{Ld}$ for each of the four anaerobic reactors evaluated.

The use of zeolite to increase the robustness of anaerobic processes with the addition of zeolite has been reported [25, 26]. Montalvo et al. [27] evaluated the performance of a UASB reactor with the addition of natural zeolite operating at high nitrogen concentrations (0.5, 0.7 and $1.0 \mathrm{~g} / \mathrm{L}$ ) and with up-flow velocities of $0.25-0.75 \mathrm{~m} / \mathrm{h}$ and HRT ranging from 1.33 to $4 \mathrm{~h}$. It was observed that COD removal was $50 \%$ higher in the zeolite-modified UASB reactor than in the reactor without zeolite addition. Likewise, Montalvo et al. [27], found that zeolites have a positive effect on the autotrophic denitrification startup process (batch mode), decreasing up to $50 \%$ the time required to achieve stabilization of the process ( $5 \mathrm{~d}$ with zeolites compared to $10 \mathrm{~d}$ without zeolites). In the continuous process the effect was similar, achieving stabilization in around $14 \mathrm{~d}$. According to previous studies [28] with the use of zeolite, it was demonstrated the positive effect they produce on the microbial consortium and on the adsorption of compounds with partial or total inhibitory effects [29]. Zeolite addition has an impact on the better performance of the archaea so this could be the possible cause to all these results.

On the other hand, the TKN values in the influent were in the range from 20 to $560 \mathrm{mg} / \mathrm{L}$, considered advantageous for increasing buffer capacity in the anaerobic digestion process [8]. The nitrogen removal efficiency showed a great variability, with results in the range from 40.0 to $95.0 \%$.

In this study, treatment with EGSB reactor achieved an average removal efficiency of total and volatile solids of 56.0 and $62.0 \%$, respectively. In this way, it can be inferred that the removal efficiency of ammoniacal and total nitrogen is closely related and was favored due to a considerable removal of solids, as well as the buffering effect observed.

Methane yield values ranging from 214.5 to $299.8 \mathrm{~mL}_{\mathrm{CH} 4} / \mathrm{g}_{\mathrm{COD}}$ were obtained under discontinuous regimen or batch experiments $\left(266.5 \pm 2.6 \mathrm{~mL}_{\mathrm{CH}} / \mathrm{g}_{\mathrm{CODin}}\right)$, demonstrating the effectiveness in methane production. For continue regime process, methane yield values were from 198.5 to $271.2 \mathrm{~mL}_{\mathrm{CH} 4} / \mathrm{g}_{\mathrm{CODin}}$ 


\subsubsection{Estimation of kinetic parameters}

All the experimental data were adjusted to the modified Stover-Kincannon model. Fig. 3 summarizes the kinetic results by plotting the inverse of the OLR observed and predicted versus the inverse of the organic removed loading rate in terms of both soluble COD and TKN. The high value of the correlation coefficient indicates a good agreement between the prediction and the experimental data for EGSB reactor. According to the results, the correlation coefficient for soluble COD was 0.99, while for TKN was 0.969 . From previous results, it could be considered that the modified Stover-Kincannon model is capable of describing the performance of the soluble COD removal for an EGSB reactor treating real piggery wastewater. The present study also showed a rate of maximum substrate utilization constant $\left(\mathrm{U}_{\max }\right)$ of $10.21 \mathrm{~g} \mathrm{COD} / \mathrm{Ld}$ and $5.16 \mathrm{~g}_{\mathrm{TKN}} / \mathrm{Ld}$ and a saturation value constant $\left(\mathrm{K}_{\mathrm{B}}\right)$ of 11.83 $\mathrm{g}_{\mathrm{COD}} / \mathrm{Ld}$ and $8.39 \mathrm{~g}_{\mathrm{TKN}} / \mathrm{Ld}$. In addition, the relationship between predicted and observed effluent soluble COD and TKN values in EGSB reactor is a linear between the observed and predicted effluent concentrations as expected showing better correlation for soluble COD than for TKN.

From the kinetic point of view, dissimilar results are provided widely by scientific reports. Jijai et al. [17] using a lab scale UASB reactor to treat cannery seafood wastewater, obtained similar results in comparison with the present study. The authors studied HRT of $5,4,3,2,1,0.5$ and $0.25 \mathrm{~d}$ with three different sources of inoculum.
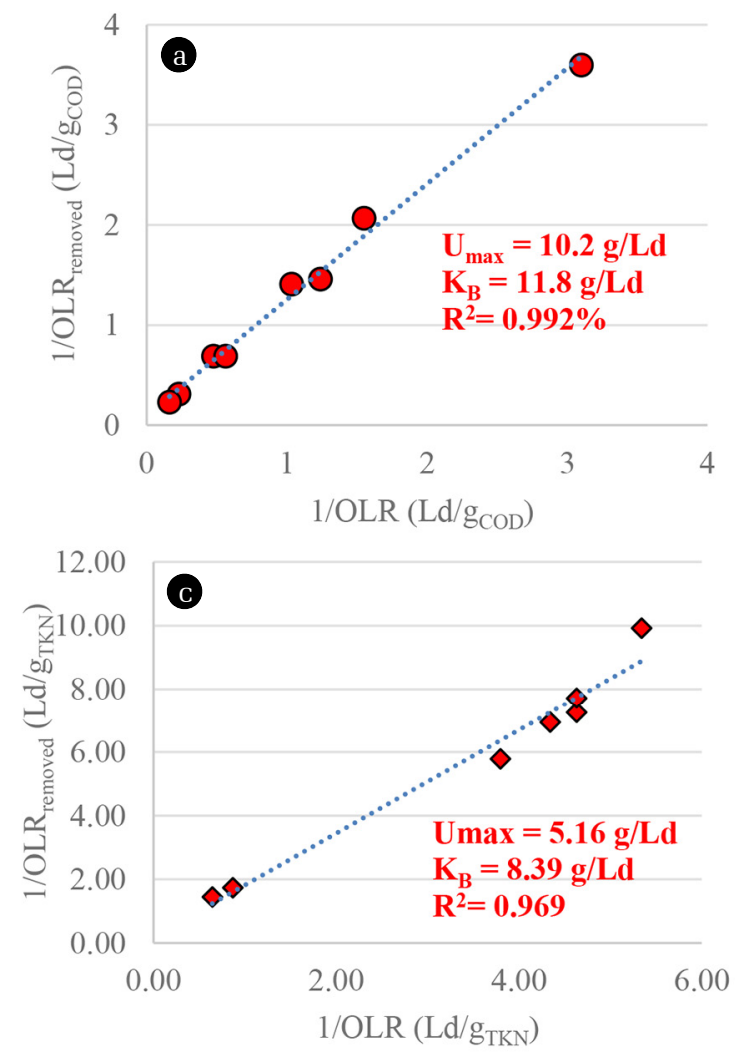

The effect of the inoculum type on biodegradability was evaluated by applying the Monod, Contois, Grau second order and modified Stover-Kicannon models to determine the substrate removal kinetics of the UASB reactor. Kinetic parameters were subsequently used to predict effluent COD. $\mathrm{K}_{\mathrm{B}}$ values from 10.28 to $24.27 \mathrm{gCoD} / \mathrm{Ld}$ and $\mathrm{U}_{\max }$ values from 10.64 to $23.87 \mathrm{gcoD} / \mathrm{Ld}$ were obtained. The results showed that the modified Stover-Kicannon, as well as the second order Grau kinetic models, were more suitable to evaluate the COD of the effluent, with a high correlation coefficient $\left(R^{2} \geq 0.98\right)$.

Hassani et al. [30] used a moving bed biofilm reactor (MBBR) treating wastewater containing ethylene glycol, and the COD removal was assessed by kinetic modeling. The results showed that the modified Stover-Kincannon model matched with experimental data $\left(\mathrm{R}^{2}\right.$ $=0.9919), \mathrm{U}_{\max }$ and $\mathrm{K}_{\mathrm{B}}$ were calculated as 13.62 and $13.14 \mathrm{~g} \mathrm{COD} / \mathrm{Ld}$, respectively. Furthermore, Abyar et al. [12] treating synthetic wastewater in an up-flow anoxic/aerobic sludge bioreactor (UAASB), reported $K_{B}$ and $U_{\max }$ values of 25.99 and 24.75 gCoD $/ L d$ respectively. These authors also reported nitrogen removal with $\mathrm{K}_{\mathrm{B}}$ and $\mathrm{U}_{\max }$ values of $0.314 \mathrm{~g}_{\mathrm{TKN}} / \mathrm{Ld}$ and $0.334 \mathrm{~g}_{\mathrm{TKN}} / \mathrm{Ld}\left(\mathrm{R}^{2}=0.96\right)$ which are much lower than the reported in the present paper.

In the case of COD removal, lower values of $\mathrm{K}_{\mathrm{B}}=5.48 \mathrm{~g} \mathrm{COD} / \mathrm{Ld}$ and $\mathrm{U}_{\max }=0.49 \mathrm{~g}_{\mathrm{COD}} / \mathrm{Ld}$ were reported by Okoli and Okonkwo [31] treating brewery wastewaters in an anaerobic fluidized bed reactor under mesophilic temperatures. These authors studied increasing hydraulic retention times from one (1) to $10 \mathrm{~h}$. COD reduc-
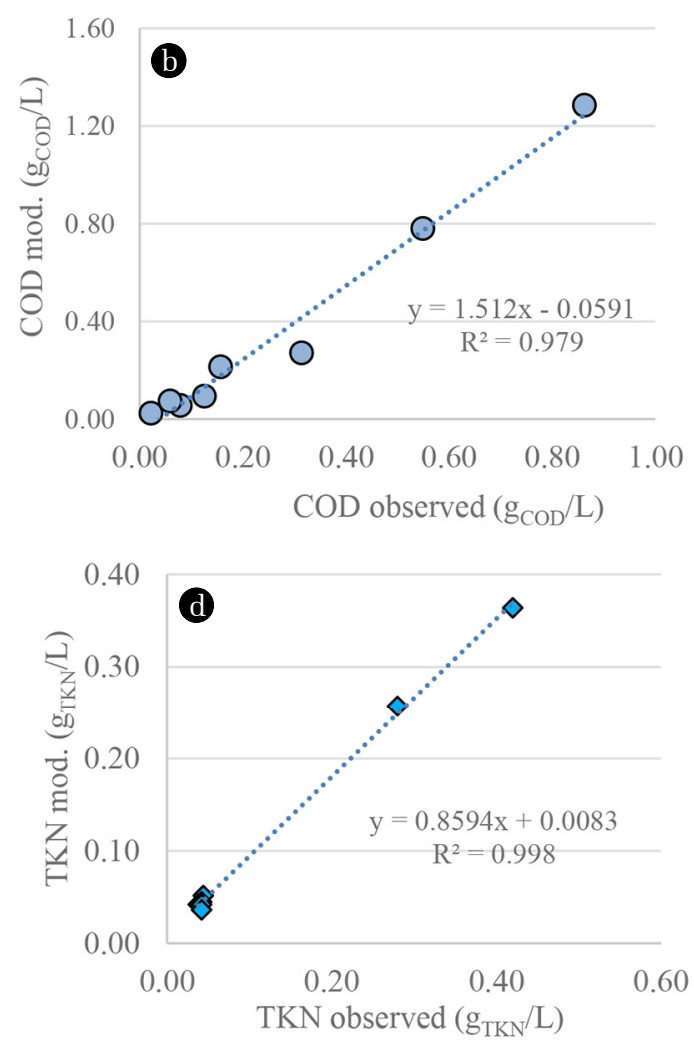

Fig. 3. Substrate removal plots and effluent COD and TKN concentration prediction according to the modified Stover- Kincannon model ( $O$ refers to $\mathrm{COD} ; \diamond$ refers to TKN) 
tion efficiencies increased from 9.8 to $74.1 \%$ when HRT varied from 2 to $10 \mathrm{~h}$. The predicted effluent concentration values from the modified Stover-Kincannon model were found to be in high agreement with the experimental values $\left(\mathrm{R}^{2}=0.99\right)$. Authors demonstrated that this model can be used to predict the COD concentration of the effluent in a fluidized bed reactor that treats wastewater from a brewery.

For instance, $\mathrm{Ni}$ et al. [32] applied the modified StoverKincannon model to simulate the nitrogen removal process of an UASB reactor. The values of $\mathrm{K}_{\mathrm{B}}$ and $\mathrm{U}_{\max }$ constants were calculated as 12.11 and $11.42 \mathrm{~g} / \mathrm{Ld}$, respectively. Accordingly, Tomar \& Gupta [33] investigated the nitrogen removal by an anammox hybrid reactor, determining values of $U_{\max }$ and $K_{\mathrm{B}}$ of 45.04 and $47.07 \mathrm{~g}_{\mathrm{TKN}} / \mathrm{Ld}$, respectively. In another study, a kinetic estimation of an UASB-anammox in terms of total nitrogen removal accomplished $U_{\max }$ and $\mathrm{K}_{\mathrm{B}}$ values like 3.33 and $4.03 \mathrm{~g}_{\mathrm{TKN}} / \mathrm{Ld}$, respectively [34].

As stated before, numerous reports expressed an appropriate correlation between observed values of COD and TKN effluent concentrations in relation with the modeled with the use of the kinetic parameters described by the modified Stover-Kincannon model. Principal differences among them are more related to operational parameters and the nature of the wastewater treated. Some wastewaters contain complex compounds which can affect or retard the microbial activity of the bioreactors, by inducing/provoking a partial or total microbial inhibitory effect.

The successful use of this model for configuration of reactors with "fluidized" granules provides a proper pathway as an important tool in the process implementation at full-scale. In addition, natural zeolite enhanced a more stable performance of the anaerobic treatment processes, as well as in removing nitrogen compounds and soluble organic matter [10].

This is a promissory alternative for piggery breeding farms of a high concentration of animals like the so-called "Integral Piggery Centers" in Cuba.

In this direction and taking into account the fluctuations of influent characteristics of Cuba pig breeding wastewaters, it would be able to project an EGSB reactor with a digestion volume defined by Eq. (3):

$$
V=\frac{Q * \operatorname{COD}_{\text {influent }}}{\left(10.2 / \eta_{\text {COD }}\right)-11.8}
$$

Where V: Digestion volume of the EGSB reactor $(\mathrm{L}), \mathrm{Q}$ is the volumetric flow $(\mathrm{L} / \mathrm{d})$, COD influent is the concentration of the chemical oxygen demand of piggery wastewater and $\rceil \mathrm{COD}$ is the expected COD removal efficiency according to the performance of the process assessed at lab scale. Values of 10.2 and 11.8 correspond to the kinetic parameters $\mathrm{U}_{\max }$ and $\mathrm{K}_{\mathrm{B}}$, respectively in gCoD/Ld. Thus, the EGSB reactor with the addition of Cuban natural zeolite provides a good alternative for the treatment of piggery wastewater, with adequate levels of organic matter removal, low HRT and high OLR.

\section{Conclusions}

The EGSB reactor with addition of Cuban natural zeolite has been evaluated for the treatment of piggery wastewater from a Cuban pig breeding farm. The results confirmed that the addition of zeolite promotes a proper anaerobic digestion performance and stability of control parameters. It was possible to apply an organic load range from $0.32-6.13 \mathrm{~g}_{\mathrm{COD}} / \mathrm{Ld}$, obtaining removal efficiencies up to $86.2 \%$. The process can be evaluated through the modified Stover-Kincannon model, predicting the soluble COD and TKN of the effluent with a high precision $\left(\mathrm{R}^{2}>0.99\right)$. EGSB reactor with the use of zeolite is an attractive alternative for large pig farms that could be scaled up to industrial level, with an additional energetic value due to the observed methane yield.

\section{Acknowledgments}

The authors would like to thank FONCI (Financial funds for Science and Innovation), Cuba, for financial support.

\section{Author Contributions}

T.P-P. (Researcher) did conceptualization, methodology, formal analysis, writing - review \& editing. A.F-M. (University student) did methodology, formal analysis, funding acquisition. A.C-D. (Professor) did methodology, formal analysis, funding acquisition. L.E.G-D. (Professor) did resources, supervision. D.O-M. (Professor) did resources, supervision. Z.M. (Engineer in Training Certified by FBPE) at VK Wastewater Treatment Plant) did resources, supervision. I.P-R. (Professor) did conceptualization, methodology, formal analysis, supervision, funding acquisition.

\section{References}

1. Xu J, Adair ChW, Deshusses MA. Performance Evaluation of a Full-Scale Innovative Swine Waste-to-Energy System. Bioresour. Technol. 2016;216:494-502.

2. Sosa R, Díaz YM, Cruz T, de la Fuente JL. Diversification and overviews of anaerobic digestion of Cuban pig breeding. Cuban J. Agric. Sci. 2014;48(1):67-72.

3. Rico C, Montes JA, Rico JL. Evaluation of different types of anaerobic seed sludge for the high rate anaerobic digestion of pig slurry in UASB reactors. Bioresour. Technol. 2017;238:147-156.

4. Xu H, Liu Y, Gao Y, Li F, et al. Granulation Process in an Expanded Granular Sludge Blanket (EGSB) Reactor for Domestic Sewage Treatment: Impact of Extracellular Polymeric Substances Compositions and Evolution of Microbial Population. Bioresour. Technol. 2018;269:153-161.

5. Zhang J, Zhang L, Loh KC, Dai Y, Tong YW. Enhanced anaerobic digestion of food waste by adding activated carbon: fate of bacterial pathogens and antibiotic resistance genes. Biochem. Eng. J. 2017;5:19-25.

6. Kong X, Yu S, Xu S, Fang W, Liu J, Li H. Effect of FeO addition on volatile fatty acids evolution on anaerobic digestion at high organic loading rates. Waste Manage. 2018;71:719-727.

7. Arif S, Liaquat R, Adil M. Applications of materials as additives 
in anaerobic digestion technology. Renew. Sustain. Energy Rev. 2018;97:354-366.

8. Montalvo S, Huiliñir C, Borja R, Sánchez E, Herrmann C. Application of zeolites for biological treatment processes of solid wastes and wastewaters-A review. Bioresour. Technol. 2020;301:122808.

9. Pérez-Pérez T, Pereda-Reyes I, Pozzi E, Oliva-Merencio D, Zaiat M. Performance and stability of an expanded granular sludge bed reactor modified with zeolite addition subjected to step increases of organic loading rate (OLR) and to organic shock load (OSL). Water Sci. Technol. 2018;77(1):39-50.

10. Pérez-Pérez T, Pereda-Reyes I, Correia GT, et al. Performance of EGSB reactor using natural zeolite as support for treatment of synthetic swine wastewater. J. Environ. Chem. Eng. 2021; 9(1):104922.

11. Padilla-Gasca E, López-López A. Kinetics of Organic Matter Degradation in an Upflow Anaerobic Filter Using Slaughterhouse Wastewater. J. Bioremed. Biodegrad. 2010;1(2): 2-6.

12. Abyar H, Younesi H, Bahramifar N, Zinatizadeh AA, Amini M. Kinetic evaluation and process analysis of COD and nitrogen removal in UAASB bioreactor. J. Taiwan Inst. Chem. Eng. 2017;78:272-281.

13. Verein Deutscher Ingenieure e.V. VDI 4630 Fermentation of organic materials - Characterization of the substrate, sampling, collection of material data, fermentation tests. 2006 ed. Düsseldorf; Deutsches Institut fur Normung E.V. (DIN); 2006.

14. APHA (American Public Health Association); AWWA (American Water Works Association); WEF (Water Environment Federation) 2017. Standard Methods for the Examination of Water and Wastewater. 23th ed. USA.

15. Lossie U, Pütz P. Targeted control of biogas plants with the help of FOS/TAC. Practice Report Hach-Lange. 2008.

16. Pagés-Díaz J, Sárvári-Horváth I, Pérez-Olmo J, Pereda-Reyes I. Co-digestion of bovine slaughterhouse wastes, cow manure, various crops and municipal solid waste at thermophilic conditions: a comparison with specific case running at mesophilic conditions. Water Sci. Technol. 2013;67(5):989-995.

17. Jijai S, Siripatana C, Sompong O, Ismail N. Kinetic models for prediction of COD effluent from upflow anaerobic sludge blanket (UASB) reactor for cannery seafood wastewater treatment. J. Teknologi. 2016;78(5-6):93-99.

18. Duda RM, Vantini JS, Martins LS, et al. A balanced a microbiota efficiently produces methane in a novel high-rate horizontal anaerobic reactor for the treatment of swine wastewater. Bioresour. Technol. 2015;197:152-160.

19. Boursier H, Béline F, Paul E. Piggery wastewater characterization for biological nitrogen removal process design. Bioresour. Technol. 2005;96(3):351-358.

20. Zhou H, Liu W. Feeding control of anaerobic co-digestion of waste activated sludge and corn silage performed by rule-based PID control with ADM1. Waste Manage. 2020;103:22-31.
21. Wilches C, Vaske M, Hartmann K, Nelles M. Representative Sampling Implementation in Online VFA/TIC Monitoring for Anaerobic Digestion. Energies 2019;12:1179.

22. Ahring BK, Sandberg M, Angelidaki I. Volatile fatty acids as indicators of process imbalance in anaerobic digestors. Appl. Microbiol. Biotechnol. 1995;43(3):559-565.

23. Zhao HW, Viraraghavan T. Analysis of the performance of an anaerobic digestion system at the Regina Wastewater Treatment Plant. Bioresour. Technol. 2004;95(3):301-307.

24. Song M, Shin SG, Hwang S. Methanogenic population dynamics assessed by real-time quantitative PCR in sludge granule in upflow anaerobic sludge blanket treating swine wastewater. Bioresour. Technol. 2010;101(1):S23-S28.

25. Huilinir C, Quintriqueo A, Antileo C, Montalvo S. Methane production from secondary paper and pulp sludge: Effect of natural zeolite and modeling. Chem. Eng. J. 2014;257:131-137.

26. Montalvo S, Huiliñir C, Gálvez D, Roca N, Guerrero L. Autotrophic denitrification with sulfide as electron donor: Effect of zeolite, organic matter and temperature in batch and continuous UASB reactors. Int. Biodeterior. Biodegrad. 2016;108: 158-165.

27. Montalvo S, San Martin J, Huiliñir C, Guerrero L, Borja R. Assessment of a UASB reactor with high ammonia concentrations: Effect of zeolite addition on process performance. Process Biochem. 2014;49:2220-2227.

28. Milán Z, Montalvo S, Ilangovan $\mathrm{K}$, et al. The impact of ammonia nitrogen concentration and zeolite addition on the specific methanogenic activity of granular and flocculent anaerobic sludges. J. Environ. Sci. Health Part A. 2010;45(7):883-889.

29. Zheng H, Li D, Stanislaus MS, et al. Development of a bio-zeolite fixed-bed bioreactor for mitigating ammonia inhibition of anaerobic digestion with extremely high ammonium concentration livestock waste. Chem. Eng. J. 2015;280:106-114.

30. Hassani AH, Borghei SM, Samadyar H, Ghanbari B. Utilization of moving bed biofilm reactor for industrial wastewater treatment containing ethylene glycol: Kinetic and performance study. Environ. Technol. 2014;35(4):499-507.

31. Okoli CS, Okonkwo PC. Substrate reduction kinetics and performance evaluation of fluidized-bed reactor for treatment of brewery wastewater. Nigerian J. Technol. 2016;35(1):91-96.

32. Ni S-Q, Sung S, Yue Q-Y, Gao B-Y. Substrate removal evaluation of granular anammox process in a pilot-scale upflow anaerobic sludge blanket reactor. Ecol. Eng. 2012;38(1):30-36.

33. Tomar S, Gupta SK. Investigating the role of co-substrate-substrate ratio and filter media on the performance of anammox hybrid reactor treating nitrogen rich wastewater. J. Biosci. Bioeng. 2016;121(3):310-316.

34. Niu Q, Zhang Y, Ma H, He S, Li YY. Reactor kinetics evaluation and performance investigation of a long-term operated UASB-anammox mixed culture process. Int. Biodeterior. Biodegrad. 2016;108:24-33. 